Verster, $\mathrm{P}$

Universiteit van die Vrystaat

\title{
Die sendingimplikasies van Kolossense 1:15-20
}

\author{
ABSTRACT \\ The implications for missions of 1 Colossians 1:15-20
}

The implications of 1 Colossians 1:15-20 concerning Christ as head of the cosmos and the church are huge. It is generally accepted that the author of this hymn used an original form of the text to generate the reworked present form. Themes such as creation, Christ as head of the church, the unity of Christ and God, reconciliation at the cross and aspects of the atonement are explained. The missiological implications are that Christ as head of the cosmos has every right on all aspects of the universe; the unity of Christ and God means that the salvation is radical and total in Him; the atonement brings total salvation from Christ who died on the cross but who was also resurrected; the Christological implications are that all powers should acknowledge that they are limited by Him who died on the cross and that the salvation entails encompassing and total welfare.

\section{INLEIDING}

Kolossense 1:15-20 is ' $n$ merkwaardige teksgedeelte. Nie alleen bevestig hierdie lied die besondere betekenis van Jesus Christus vir die kerk nie, maar dit maak ook die kosmiese betekenis van Jesus Christus duidelik. Christus is hoof van die kerk en die heelal. Christus se hoofskap hang egter ook ten diepste met sy versoeningswerk saam. Die universele aard van die versoening kom ook sterk na vore. Vir die sending het dit verskeie implikasies en die teenwoordigheid van die volheid van God in Christus beteken ook dat die sending hierdie waarheid sal moet verkondig. Die feit dat Jesus die Here van die heelal is, het die implikasie dat Hy die wonder van God ten volle vertoon.

\section{NAVORSINGSVRAE}

Die vraag wat gestel moet word, is: Wat is die implikasie van Christus se hoofskap in die versoening vir die kerk en die wêreld? Dit beteken dat'n mens ook sal moet beoordeel op watter wyse Christus se versoeningswerk nie alleen die kerk bepaal nie, maar ook die wêreld in al sy verbande. Sou dit' $n$ omvattende benadering tot die sending onderlê, en indien wel, op watter wyse?

\section{ONTLEDING}

Ten spyte van die feit dat daar verskeie standpunte oor die teksgedeelte is, is daar redelike konsensus dat dit ' $n$ himne is. "The striking character of the language used in the middle section of the first chapter of Colossians suggests the identification of vv. $15-20$ as a separate hymnic unit: a glorification of the Son of God as co-creator of the universe and the one in whom God reconciles all to Himself (Behr 1996:247; vgl. egter Harris 1991:41 wat van mening is dat sekere stylfigure nie noodwendig ' $n$ himne veronderstel as daar nie ' $n$ duidelike metriese patroon is 
nie). Dit beteken nie dat daar ' $\mathrm{n}$ lied in die moderne sin van die woord voorkom nie. Sekere stilistiese elemente wat voorkom, dui egter op die himniese karakter van die gedeelte. Baugh (1985:228) skryf: "I find, however, that the structure of Col 1:15-20 can indeed be identified without reconstructing the text. In its details it is quite intricate; nevertheless, the overall pattern is a simple chiasm much like poetry and prose from the OT and from other Semitic works... This assumes that we can rank the Colossians poem as a type of Semitic versus some other kind of poetry."

Oor die Pauliniese outeurskap van die gedeelte is daar geen eenstemmigheid nie. Daar is verskeie eksegete wat nie die outeurskap van Kolossense aan Paulus toeskryf nie, en ook nie dié van die himne nie (vgl. Helyer 1983:170,171 vir 'n volledige oorsig oor die vraagstuk). O'Brien (2002:xli e.v.) beklemtoon egter wel dat Paulus die outeur kan wees. Hy sou ook deur die redigering van die gedeelte die outeur van die himne kon wees. Hy verwys na argumente teen die Pauliniese outeurskap en toon aan dat so'n beoordeling nie aanvaar behoort te word nie. "Such a judgment in our view appears to be unduly negative and presupposes an almost infallible understanding of what Paul could or could not have done. It also does not really explain the close similarities between Colossians and the generally accepted Pauline letters,..." (kyk ook na Guthrie [1974:554] en Kümmel [1975:346] vir aanvaarding van die Pauliniese outeurskap). Brown (1997:610-615) is egter veel meer huiwerig en na deeglike oorweging besluit hy teen Pauliniese outeurskap (kyk ook na Schweizer [1982:59]), terwyl Barclay (2001:35) versigtig is om 'n keuse uit te oefen (kyk ook na Standhartinger [1999:29 e.v.] oor die pseudepigrafiese werke in die Nuwe Testamentiese tyd].

Dit is dus nie duidelik of ons hier met 'n deeglik gekonstrueerde himne te doen het nie, maar wel dat sekere stylfigure dit veronderstel (O'Brien 2002:32 e.v.). Ook Guthrie (1981:352) wys op die ritmiese vorm, ongebruiklike woordeskat en verhewe styl as himniese karaktertrekke. Schweizer (1982:63e.v.) probeer selfs om die oorspronklike himne te rekonstrueer. Barclay (2001:59) meen dat dit nie ooreenkomste met hellenistiese of Joodse himnes toon nie, maar dat dit wel sekere himniese karaktertrekke vertoon. Dunn (1996:83-84) beskou dit wel as 'n himne in oorspronklike vorm. Okure (2002:64) is van mening dat dit ' $n$ lied is wat by die doop gesing is.

Sekere parallelle gedeeltes kom voor. O’ Brien (2002:36 e.v.) toon dit volledig aan:

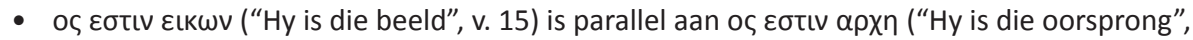
v. 18).

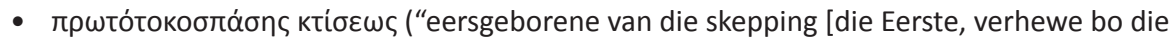

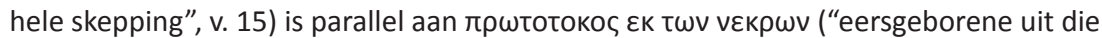
dood. [Hy is die Eerste, die Een wat uit dood opgestaan het]", v. 18).

- Verder word elkeen van die die relatiewe sinne deur gevolgsin gevolg, 'n sinsnede wat begin met otı ("omdat"):

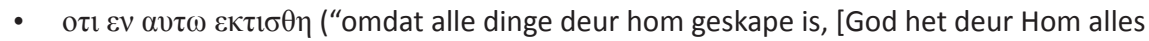
geskep]", v. 16); en

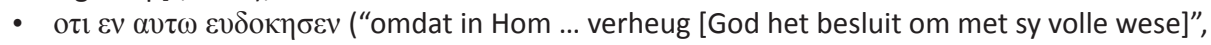
v. 19).

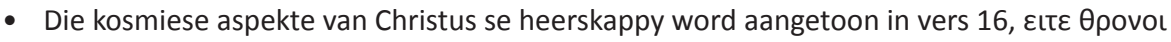

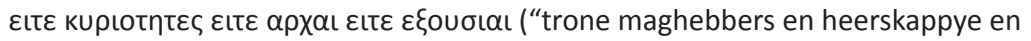
gesagvoerders"[konings, heersers, maghebbers, gesagvoerders]) en vers 20, $\varepsilon \iota \varepsilon \tau \tau \alpha \varepsilon \pi \mathrm{c}$

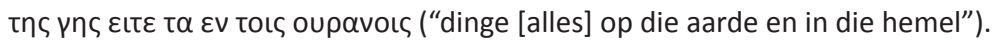

Verder kry'n mens die frekwensie van ras ("alles") en die formele chiasme in 16c and 20: 


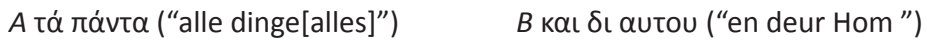

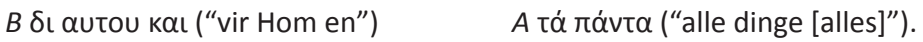

In vers 16 kom twee voorbeelde van chiasme voor. Twee reëls kom voor in 'n chiasme van sinonieme parallelisme:

\author{
o $1 \varepsilon v \alpha v \tau \omega \varepsilon \kappa \tau 1 \sigma \theta \eta \tau \alpha \pi \alpha \nu \tau \alpha$

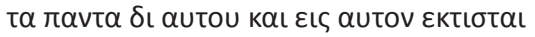 \\ "want in Hom is alle dinge geskep [God het deur Hom \\ alles geskep]" \\ "Alle dinge is vir Hom en deur Hom geskep"
}

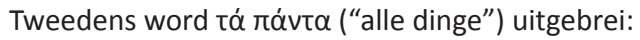

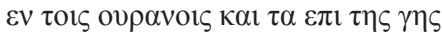

$$
\begin{aligned}
& \tau \alpha \text { ор } \alpha \tau \text { к } \alpha \iota \tau \alpha \alpha \rho \alpha \tau \alpha \\
& \text { "In die hemel en op aarde, }
\end{aligned}
$$

Sigbare en onsigbare dinge [alles wat gesien kan word en alles wat nie gesien kan word nie]"

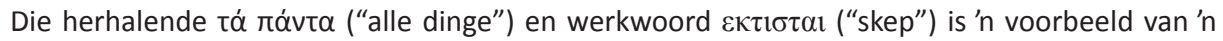
inclusio wat die tweede chiasmus bind. Die formele korrespondensie tussen 17 and 18 moet ook aangetoon word:

17

18

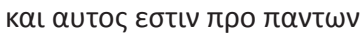

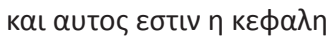 \\ "en [voor alles was Hy al daar] ... \\ En [Hy is die hoof] ..."
}

Hierdie verduideliking deur O'Brien (2002:36 e.v.) bevestig dat daar wel 'n sterk himniese karakter aan die teksgeldeelte is.

Dit is duidelik dat Paulus standpunt inneem teen ' $n$ dwaalrigting waarvan die aard onseker is, al word gnostiek en misteriegodsdiens dikwels aangedui ( Barth and Balke 1994:21-23). In die dwaalrigting word Christus se heerskappy bevraagteken en die volkomenheid van sy verlossingswerk aan bande gelê. Hierteenoor stel Paulus Christus se totale en volstrekte uniekheid (Roberts 1984:150). Barclay (2001:40-48) gee 'n volledige oorsig oor standpunte oor die saak waarteen Paulus polemiseer naamlik, Joods-Christelike gnostiek, 'n verchristelikte misteriegodsdiens, mistieke Joodse geloof, Hellenistiese filosofie en sinkretistiese volksgeloof. Guthrie (1981:353) veronderstel 'n Joodse agtergrond vir die himne. Hy veronderstel ook dat 
Paulus polemiseer teen die gedagte dat die Torah verhewe is deur Christus se verhewenheid te beklemtoon. Barclay (2001:67) hanteer die saak vanuit die standpunt dat dit 'n kreatiewe teologiese ontwikkeling is waarin Christene heidense konsepte met die opgestane Christus in verband bring soos die hellenistiese Jode die hellenistiese filosofie met Joodse wysheid vermeng het. Dunn (1996:90) beklemtoon ook dat die element van wysheid ' $n$ belangrike rol in die gedeelte speel. Witherington III (2007:130) toon volledig aan dat daar elemente is wat ooreenstem met die Wysheid van Salomo ten opsigte van die rol van wysheid en dat daar dus ook verwysings na die Joodse begrip voorkom.

\section{HOOFTEMAS}

Sekere hooftemas kom in die gedeelte sterk na vore.

\subsection{Skepping}

Die verband tussen die gedeelte wat Christus as die Eerste voor die skepping stel en Genesis verbind die heil in Hom met die skeppingsteologie. As beeld van God is die Seun die een deur wie die hele skepping in sy volheid geskape is. Die Seun as beeld van God is egter van ' $n$ ander aard as Adam, wat skepsel is. Die beeld van God dui op'n verteenwoordiger of manifestasie van God (Schweizer 1982:66). Thompson (2005:29) wys op die implikasies van Christus as beeld van God. Die onsigbare God is in Hom sigbaar en verder is Hy die volle beliggaming van God soos die wysheidbeeld dit vertoon. Lohse (1971:48) beskryf dit soos volg: "As the 'image' of the invisible God, he does not belong to what was created, but stands with the creator who, in Christ, is acting upon the world and with the world." Dit is God se heiligheid wat in Christus gestalte vind (Lähnemann1971:47). Die Seun is self die een deur wie geskep word. Hy is egter nie slegs die Skepper van die fisiese, sigbare wêreld nie, maar heers ook oor die onsigbare magte en heerskappye. Uitman (1978:32) toon aan dat dit juis nie die magte is wat aanbid moet word nie, maar Jesus self. Teenoor die "af"goddelike magte is die een wat aanbid moet word waarlik God. Christensen (2007:318) beklemtoon dat: "Christ is not an example of something else, neither a universal principle nor an abstract rationality. He is, in his person and work, the actual presence and activity of the living God." Ook Gundry (2010:12) bevestig dat die Seun deur die inkarnasie die onsigbare God sigbaar maak. Witherington III (2007:133) beklemtoon dat die ooreenstemming tussen Christus en God nie in uiterlike voorkoms geleë is nie, maar in die volledige verteenwoording van God in Christus.

Martin (1972:40-42) toon aan hoe die vraag of die skeppingsteologie in die teks deur die gnostiek beïnvloed is, bevraagteken moet word omdat die gnostiek waarskynlik nie vroeg ontwikkel het nie, en omdat'n mens waarskynlik eerder die agtergrond in die Joodse wysheid as in die gnostiek moet soek. Kolossense beskou die heerlikheid van Christus as skepper in samehang met die wysheid van God en met die personifisering van die wysheid in die Ou Testament (Bruce 1977:124). Christus is die volle wysheid van God (Thurston (1995:33). Bruce (1984:102) skryf in hierdie verband: "Whatever other figures in Jewish literature may have préexistence ascribed to them, none of them is credited with such cosmic activity and significance as are here predicated of the préexistent Christ."

Die Seun se heerlikheid word verder bevestig deurdat Hy die een is vir wie alles geskape is. Verder word die voorsienigheidsleer bevestig daarin dat die Seun die een is wat alle dinge in stand hou. Christus is dus nie alleen die een wat die skepping inisieer nie maar ook die Een wat dit bewaar (Carson 1983:43). Hiermee word ineens die wonder vasgelê van die Seun as die Een wat die hele skepping bepaal (vgl. Kümmel 1975:336). Die Seun is inderdaad die eniggebore van God en die verband met Johannes 1 is ook duidelik. Die himne bevestig die Seun se heerlikheid. 
Hierdie heerlikheid oorspan die hele heelal. Uitman (1978:34) noem dit die leitmotiv van die hele brief.

Hierdie leitmotiv bepaal die skepping in al sy verbande. Geen aspek van die heelal is van die heerskappy van Christus uitgesluit nie. Die skeppingsteologie word so op radikale wyse aan Christus verbind. In Ou Testamentiese verband word die skepping bepaal deur God self wat die dinge tot aansyn roep, en God se heerlikheid word daardeur bevestig. Jesus Christus self word nou die een wat die skepping bepaal (Witherington III 2007:134). Dit beteken dat God en Christus, as eenheid, self radikaal in die heerlikheid deel. Die skeppingstaal is egter volledig. Guthrie (1981:356) skryf dan ook: "In no clearer way could he have set Christ at the very centre of creation, and in no more explicit terms could he have asserted his superiority." Goppelt (1982:77) stel dit soos volg:

Being the agent of creation meant accordingly not merely participation in an event at the beginning but the enduring relationship to the cosmos. He was the 'first-born of all creation' (v. 15b) not because he was the first one to be created and as such would introduce the succession of that which was created, but because he 'is before all things' (v. 17).

Dit beteken ook totale oorwinning. Wilson (1997:197) praat daarom van God se kosmiese oorwinning wat daarin geleë is dat Christus ook oor die kosmiese magte triomfeer. Dit is dan juis Christus wat die magte onttroon en deur sy rol in die skepping en sy versoenende dood aan die kruis sy heerskappy toon (Thompson 2005:9).

\subsection{Christus se hoofskap oor die kerk}

Harris (1991:43) verduidelik dat die onsigbare God wat'n ontoeganklike lig bewoon Hom sigbaar in sy Seun openbaar. Die verhouding tussen Christus en die kerk word egter ook duidelik vasgelê. Die heerlikheid van die Een wat die beeld van God is, maar juis in sy verhewenheid bo die skepping is, bevestig ook sy heerlikheid as Hoof van die kerk. Die eie unieke aard van die kerk word sterk bevestig. Hy is nie alleen die Hoof van die kerk nie. Hy is ook die oorsprong daarvan. As Here van die heelal is Hy in besonder die Here van die kerk (kyk na Guthrie 1981:357). O'Brien (2002:49) skryf:

We consider, then, that it was Paul, rather than some unknown redactor, who is the originator of this way of expressing the church's vital union with Christ, the head (cf. Col 2:19). Using the Old Testament concept of corporate personality and by referring to "body" $(\sigma \omega \mu \alpha)$ and "head" ( $\kappa \varepsilon \phi \alpha \lambda \eta \dot{)})$ as he does, he has made his own distinct contribution to NT Christology and ecclesiology."

Christus is die Een wat bepaal wat die kerk is. Dit beteken dat die kerk inderdaad die skepping van Christus is. Christus is die Hoof van die skepping en ook van die kerk. Die Here van die kerk is die onbetwiste Here van die Koninkryk van God. Waar die Hoofskap van Christus in Efesiërs op die kerk van toepassing is, word dit in Kolossense na die hele wêreld uitgebrei (vgl. Uitman 1978:7).

\subsection{Die eenheid van Christus en God}

Die Christologie bepaal dus hierdie benadering op 'n besondere wyse (Standhartinger 1999:217). Deur die opstanding word bevestig dat Hy die eerste plek in die heelal inneem. Die opstanding bevestig die hoofskap van Christus oor die kerk en die wêreld. Die eenheid met God is dus nie onderhandelbaar nie en word in die gedeelte radikaal bevestig. Die eenheid met God bevestig dus die wonderbare erkenning dat Christus die Here is. Guthrie (1981:358) toon aan dat die 
Godheid van Christus juis daarmee bevestig word. Tripp (2004:78) toon in geen onduidelike taal die eenheid aan: "Christ is the image of God, and, as the firstborn before all creation, the instrument of creation, so that his relationship with the Father is the matrix and model of their shared work of creation. As the means of the reconciliation of all creation with the Father, he is (the texts say at least this much) indwelt on a permanent basis by the full being of deity."

\subsection{Die versoening aan die kruis}

Christus se eenheid met God lei dan ook tot die versoening omdat God die versoening in Christus Trinitaries bewerk. Daarmee verkry die versoening 'n eie goddelike karakter. God woon met sy volle wese in Christus. Hy versoen alles deur Hom met Homself. Volgens Uitman (1978:36) gaan dit nie om idees of gedagtes of spekulasies nie, maar om 'n heilswerklikheid met reële gebeure en handelinge deur God waar Hy Homself offer, gee en oorgee in Jesus Christus. Guthrie (1974:551) bevestig Christus se "immeasurable superioriy" in teenstelling met die voorstelling aangaande Christus deur die dwaalleraars van die Kolossense. Die werklike belewenis van die versoening beteken dat die heil in Christus in die tyd werklik word (Wall 1993:70). Die versoening is ' $n$ radikale daad van God. Dit is nie die mens wat God beïnvloed of aanmoedig om 'n nuwe verhouding te skep nie, maar God in Jesus Christus wat die daad van versoening moontlik maak (Schnelle 2003:454).

\subsection{Die totale reikwydte van die versoening.}

O’Brien (2002:56) beklemtoon die universaliteit van die versoening:

Paul affirms that this universal reconciliation has been brought about, not in some otherworldly drama, but through something done in history, the death of Jesus Christ upon the cross.

Die versoening het dus 'n sterk universele betekenis. So kan die betekenis van die volledige heil wat Christus bring, bevestig word (Guthrie 1981:358). As sentrale tema is die versoening bepalend vir die verlossing van die wêreld. Die bedreiging deur die magte en heerskappye is dus verbreek. Die kruis van Christus het die radikale hoop na vore laat tree. Hierdie hoop is volledig omdat dit ook universeel is. Die versoening strek dus verder as die kerk, maar sluit dit ook in. Vanuit hierdie universele heil moet die koningskap van Christus beklemtoon word. Ook Brown (1997:604) bevestig Christus se totale heerskappy: "By divine election God in all fullness dwells in Christ. That is why through him all things can be reconciled to God" (1:20a). Carson (1983:46) beklemtoon ook die reikwydte van die versoening. Wall (1993:69) skryf: " To deny Christ as the Lord of God's creation is to deny the redemptive consequences of Christ's death; to reject God's desire to delight in the inherent goodness of creation is to reject the prospect of a new creation of redeemed humanity in Christ." Pokorný (1987:66) wys daarop dat die eskatologiese werklikheid hier in Christus reeds'n aanvang neem.

Die werk van Christus is egter in die versoening van wesenlike belang. Dit vind nie los van Christus plaas nie en kan daarom nie universele versoening wees nie (Martin1972:49). Ook Schweizer 1982:93) beklemtoon die radikale aspek van die versoening, maar hy beklemtoon dat dit in die geloof in Christus neerslag vind. Peterson (2010:44): "Colossians 1:20 teaches, then, not "cosmic salvation" or even "cosmic redemption," but "cosmic restoration" or "renewal." Through the work of Christ on the cross, God has brought his entire rebellious creation back under the rule of his sovereign power." 


\section{TEOLOGIESE IMPLIKASIES}

Christus se wonderbare verlossing wat universele implikasies het, word in hierdie gedeelte uitgewerk. Dit beteken dus juis dat Christus self verheerlik word. Dit wat Hy doen, bevestig self ook die heerlikheid van die verlossing wat Hy bewerk het. Die universele betekenis daarvan is dus wonderbaar en die heil se reikwydte dus totaal.

Niks en niemand kan van die betekenis van die heil uitgesluit word nie. Die reikwydte sluit alle magte, heerskappye en mense en koninkryke in. Christensen (2007: 319) verduidelik dit soos volg: "The writer of Colossians is clear: Christ is Lord over all other powers and authorities, even supernatural ones. Proponents of the false teachings in Colossae (see 2:8-13) probably saw these other beings as rivals of Christ, or they saw in the existence of those other powers the opportunity to 'hedge their bets' by giving allegiance to those other powers alongside Christ. Barth en Blanke (1994:201-202) wys op hulle beurt daarop dat verskeie standpunte oor die magte en heerskappye voorgedra word, maar dat dit na alle waarskynlikheid op alle strukture en instellings dui.

Daar is twee aspekte wat verreken moet word. Die een is dat die versoening inderdaad universeel is en alle aspekte van die bestaan insluit. Die ander is dat dit nie veronderstel dat universalisme bevestig word nie. Shultz (2010:444) skryf: "The Bible clearly rules out universalism, but it also teaches that all things created by God are reconciled to God through Christ's death. Therefore the Bible teaches universal reconciliation, but not universal salvation."

Die beklemtoning van Christus se heerlikheid bevestig aan die een kant die universele karakter van die heil. Aan die ander kant beteken dit ook dat die heil nie anders as juis in Hom gevind kan word nie. Hy is Here en dit sluit die moontlikheid van ander verlossers uit.

\section{SENDINGIMPLIKASIES}

Kolossense skakel met Jesaja 19:19-25 en alhoewel dit nie beteken dat die heil universalisties verstaan moet word nie, beteken dit tog dat die verlossing volledig universeel is. In Jesaja 19 word op unieke wyse aangetoon dat God nie slegs vir Israel heil bewerk nie maar ook vir Egipte en Asirië, die vyande van Israel. Hierdie wonderlike volledige heil neem nie weg dat in Jesaja die oordeel wel ook voorkom nie. Vir die Christologie beteken dit dan inderdaad dat Christus die Here van die kerk en die heelal is. Vir die sending het dit radikale implikasies.

\subsection{Die hoofskap van Christus oor die heelal beteken dat Hy reg op alle aspekte van die heelal het}

Hierdie universele aspek van die heil bevestig die wonder van Christus se heerskappy. Hy is die een wat op alle wesens, geskape werklikhede en magte reg het. Vir die gebroke werklikheid skep dit die hoop op 'n nuwe werklikheid, asook die nuwe verwagting op hierdie nuwe hoop. Kolossense toon hiermee juis aan hoe dat die vernuwing van die gebroke werklikheid moontlik is. Die werklikheid is nie ' $n$ totale put van ellende nie. Groter as die bedreiging vir die skepping en geskapenes is die verwagting van die heil wat in Christus verkry kan word. Hy is dus nie bloot 'n geskape wese nie, maar in werklikheid die hoof oor die geskape werklikheid. So verkry die werklikheid nuwe inhoud in die sin dat Hy daaroor heers. Dit is juis die groot bydrae van die ontwikkeling van die gereformeerde beskouing wat God se heerskappy in Christus oor die hele skepping bevestig. Die sending kan juis vanuit hierdie verhouding 'n nuwe blik op die werklikheid in Afrika verkry en lewer (Van der Walt 2003:545-551).

Dit beteken verder ook dat die afgode afgewys moet word. Christus alleen is Here (Smit 1986:31). Ook Walsh en Keesmaat (2004:89) wys daarop dat Paulus om die hart van die gemeente 
veg om dit juis teen die magte van die koninkryke van hierdie wêreld stelling te laat inneem: "In a culture of power as truth, we need servant communities ministering to the most vulnerable to demonstrate that truth is on a cross. In a culture of radical uncertainty, we need preaching and liturgy that build the body of Christ, where truth takes on flesh." Christus versamel as hoof van die kerk vir Hom 'n gemeente tot eer van God. Hy roep die mense om hulle voor God te verootmoedig en by die gemeente aan te sluit.

Christus se hoofskap sluit ook die kerk in. Die kerk kan nou nie los van die heelal gedink word nie. Die kerk as liggaam bestaan in die heelal waarin Christus ook die hoof is. Die kerk is dus die gemeenskap wat in die noue verbintenis met die hoof lewe en so ook die heil vertoon. In die kerk is die hoofskap van Christus so teenwoordig dat dit duidelik is dat die heil' $n$ werklikheid is en ook dat die heil die totale werklikheid kan deursuur.

Dunn (1996:104) vat dit saam:

It says much for the faith of these first Christians that they should see in Christ's death and resurrection quite literally the key to resolving the disharmonies of nature and the inhumanities of humankind, that the character of God's creation and God's concern for the universe in its fullest expression could be so caught and encapsulated for them in the cross of Christ (cf. already 1 Cor. 1:22-25,30).

Verder is dit duidelik dat die totale lewe in die eenheid met die Christusgebeure nou die gelowige stempel. Jesus Christus is die begronding van die nuwe lewe. Die kerk leef uit hierdie begronding (Schnelle 2003:551).

\subsection{Die eenheid van Christus met God beteken dat die heil volledig en totaal in Hom is}

Christus is een met God. Die volheid van God woon in Hom. Hy maak die verlossing totaal moontlik, alleen omdat God die een is wat in sy volheid in Christus woon. Die Goddelike heerlikheid stempel daarom die bestaan van die mens.

Maier (2005:338) dui aan hoe volledig die heil in Christus is:

All this brings into striking relief the panegyric affirmations of Colossian Christology. An early Christian audience listening to Col. 1.15-23, with its charged diplomatic language, surrounded by imperial imagery celebrating the cosmic and earthly concord of Roman rule, could not have helped but recognize imperial overtones in the celebration of an incarnate Son in whom the fullness of God dwelt $(1.19 ; 2.9)$ to bring about a universal reconciliation. Like Nero, whom imperial poets acclaimed as an embodied deity, and Seneca celebrated as the head of the body, the Roman Empire, on whom all rests and depends for its health and vigour, the incarnate Son, the enthroned Jesus, heads the cosmos by which all things hold together (1.17) and from whom, in the "empire [ $\beta \alpha \sigma i \lambda \varepsilon i \alpha]$ of his beloved Son" (1.13) comes growth and renewal $(2.9-10,19 ; 1.6)$.

Die toekoms van die mens word bepaal deur die lof aan die hoof wat die volheid van God vertoon. Die nuwe werklikheid is dus moontlik omdat die hoof van kerk en heelal self die volheid van God vertoon. Daar kan geen twyfel bestaan dat die Godheid van Christus soos nog nooit vantevore bevraagteken word nie en dat die sending juis ten opsigte van hierdie waarheid onomwonde moet getuig dat Jesus één met God is. Migliore (2004:177) skryf daarom: "God acts, suffers, and triumphs in and through Jesus. In Jesus Christ we do not have less than God's very own presence in our humanity. In this person the eternal God suffers and acts for our salvation." 


\subsection{Die versoening is heilbrengend in Hom wat sy lewe gegee het aan die kruis maar ook opgestaan het uit die dode}

Nêrens verkry die hoofskap van Christus meer indringende betekenis as wanneer aangedui word dat Hy die Een is wat aan die kruis gesterf het om die versoening te bewerk nie. Hierdie versoening het deur middel van die opstanding tot volledige heil gelei. Okure (2002:62) verduidelik hoedat 'n missiologiese lees van Kolossense moontlik is.

Missiological reading here refers primarily to how the letter can be read to promote an atmosphere where Christians and peoples of other faiths can live and work together as God's children and members of the one human family, respecting the religious freedom of each, and yet, for Christians, without ceasing to proclaim Jesus as God's gospel or Saviour of humanity. The letter to the Colossians addresses in its own context, though in different terms, the questions of the uniqueness, unicity and salvific universality of Jesus. It therefore poses a serious challenge to missiology today within the contemporary background of religious pluralism.

Kruis en opstanding verkry sodoende ' $n$ bepaalde intensie wat die hoofskap van die Here verder invul. Die hoofskap kom uit God maar word ook deur die verlossing en versoeningsdade van die kruis en die opstanding bepaal. Dit het ook kosmiese betekenis. Die heelal word bepaal deur die hoof wat juis die een is wat in sy eenheid met God uit die dood opgestaan het. Die nuwe lewe volg hieruit sodat Thompson (2005:12) skryf: "In Christ, appropriate conduct is self-giving, directed towards the other, and colored by humility, graciousness, truth and love."

Sending wat nie die volheid van die heil vir kerk én kosmos deurgee nie, is altyd beperkend. Dit beteken dat die sending juis in gehoorsaamheid en in diens aan die hoof die volheid van God moet vertoon. Dit sluit die volle skepping in. Die heil sluit die mens in die bestaan op aarde in, sowel as sy hoop op die ewige lewe. Die ekologiese aspekte word dus ook erken. Nie alleen moet die skepping as God se werk erken word nie maar ook moet die mens verantwoordelikheid vir die gesonde hantering van die skepping aanvaar. Nie alleen onder die huidige omstandighede moet met groot respek met God se hele skepping omgegaan word nie - soos om besoedeling teen te werk - maar ook wat die toekoms betref, moet gestreef word na riglyne vir ' $n$ ekologies vriendelike gemeenskap (Conradie 2006:195). Die hoofskap van Christus oor die heelal beteken die nuwe aarde moet reeds sigbaar word in die versorging van die wêreld wat tot ons beskikking is. Die hoof is hoof van die kerk wat die versoening en verlossing vir mense in hierdie wêreld maar ook in die ewigheid beteken, maar die hoof is ook hoof van die heelal wat die totale vernuwing van die totale skepping insluit. Trevethan (1981:44) dui aan dat dit baie duidelik moet wees dat ' $n$ dualistiese benadering, waar Christus slegs vir'n geestelike wêreld van belang is, nie volhoubaar is nie omdat Hy die Here van die kerk en die skepping is. Die bydrae van Bosch (1991:511-519) vir die sending word juis gestempel deur sy beklemtoning van die heilsgebeure in Christus. Al God se dade, vanaf die inkarnasie waar God radikaal ingegryp het tot by die wederkoms waar die tyd voltooi word, bevestig God se heerlike aanvaarding van die mens en die skepping.

\subsection{Die Christologiese implikasies van die heil is dat alle magte moet erken dat dit beperk word deur die Een wat volledige heil bring}

In hierdie werklikheid stuit ons teen die magte wat in die wêreld voorkom. Die magte skyn onoorwinlik te wees. Die hoof oor die kosmos is die een wat die magte onttroon. Juis Hy is die een wat as hoof die heil bring waarin die magte moet erken dat daar een is wat heerliker en sterker en magtiger is as die magte van die wêreld, al is dit die mag van die gekruisigde wat swak geword het om te verlos. Christus self bring die heil wat die heelal insluit. Hierdie vrede kom 
deur die bloed van Christus. God se heiligheid word deurgaans beklemtoon en slegs in Christus kan daar herstel kom (Witherington III 2007:136).

\subsection{Herstel in alle verbande is dus essensieel}

Jesus is die een wat die herstel bring. In sy heerlikheid maak Hy alle dinge moontlik, juis omdat Hy die Here is. Die Hoof wat deur sy lyding sy Hoofskap, wat van 'n ander aard as gewone aardse hoofskap is, bevestig het, bring die heil vir die gemeenskap. Gundry (2010:15) wys daarop dat die volheid van God juis die volledige versoening in die Seun moontlik maak deur die vrede wat Hy met sy bloed aan die kruis bewerk het. In Christus is die sending en die koninkryk ten diepste aan mekaar verbonde (Moreau et al 2004:81). Die gevolg is dat die Christelike sending in die geskiedenis op ongeëwenaarde wyse heilbrengend op mense en gemeenskappe ingewerk het (Webster 1982:765). O’Brien (1995.63) dui ook aan dat die essensie van die boodskap van die sending by Paulus juis die aankondiging van die ware hoop was. Ten spyte van die swakheid van die kerk bring die heil in Christus op alle terreine nuwe hoop. Dit is alleen moontlik vanuit die perspektief van die hoofskap van Christus oor kerk en heelal.

\section{SLOT}

Die himne in Kolossense is die bevestiging van die hoofskap van Jesus Christus tot heil van die heelal en tot verbreking van die magte van diktatuur en misdadigheid en die heil wat kom in die wonder van dít wat Hy bewerk. Niks en niemand kan meer deur sy heerlikheid onaangeraak wees nie.

\section{BRONNELYS}

Barclay, J.M.G. 2001. Colossians and Philemon. Sheffield. Sheffield Academic Press.[New Testament Guides].

Barth, M. \& Blanke, H. 1994. Colossians: A new translation with introduction and commentary. (Translated by A.B. Beck.) New York: Doubladay. [The Anchor Bible].

Baugh, S.M. 1985. The poetic form of Col 1:15-20. Westminster Theological Journal 47(2): 227-244.

Behr, J. 1996. Colossians 1:13-20: A chiastic reading. St Vladimir's Theological Quarterly, 40(4):247-264.

Bosch, D.J. 1991. Transforming mission: Paradigms shifts in theology of mission. Maryknoll, New York: Orbis.

Brown, R.E. 1997. An introduction to the New Testament. New York: Doubleday.

Bruce, F.F. 1977. Paul: Apostle of the Free Spirit. Exeter: Paternoster.

Bruce, F.F. 1984. Colossian problems, pt 2: The "Christ hymn" of Colossians 1:15-20. Bibliotheca Sacra 141(562): 99-111.

Carson, H.M. 1983. The epistles of Paul to the Colossians and Philemon: An introduction and commentary. Tyndale New Testament Commentaries. Leicester: InterVarsity.

Christensen, R.L. 2007. Colossians 1:15-28. Interpretation 61(3):318-320.

Conradie, E. 2006. Waar op dees aarde vind mens God? Op soek na 'n aardse spiritualiteit. Wellington: Lux Verbi. BM.

Dunn, J.D.G. 1996. The epistle to the Colossians and to Philemon: A commentary on the Greek text. Grand Rapids Mi: Eerdmans, [The New International Greek Testament Commentary]

Goppelt, L. 1982. Theology of the New Testament. Volume 2. The variety and unity of the apostolic witness to Christ. (Translared by Alsup, J) Grand Rapids Mi: Eerdmans

Gundry, R.H. 2010. (e Book edition 2011.) Commentary on Colossians and Philemon. Grand Rapids: Baker Academic.

Guthrie, D. 1974. New Testament Introduction. London: Inter-Varsity.

Guthrie, D. 1981. New Testament Theology. Leicester: Inter-Varsity.

Harris, M.J. 1991. Colossians and Philemon. Grand Rapids Mi: Eerdmans 
Helyer, L.R. 1983. Colossians 1:15-20: Pre-Pauline or Pauline? Journal of the Evangelical Theological Society 26(2):167-179.

Kümmel, W.G. 1975. Introduction to the New Testament. London: SCM. [New Testament Library] Lähnemann, J.1971. Der Kolosserbrief. Gütersloh: GütersloherVerlagshaus Gerd Mohn.

Lohse, E. 1971. Colossians and Philemon: A commentary on the epistles to the Colossians and Philemon.

(Translated by WR Poehlmann and RJ Karris). Philadelphia: Fortress. [Hermeneia- A critical and historical commentary on the Bible]

Maier, H.O. 2005. A sly civility: Colossians and empire. Journal for the Study of the New Testament 27(3):323-349.

Martin, R.P. 1972. Colossians:The church's Lord and the Christians liberty. Exeter: Paternoster.

Migliore, D.L. 2004. Faith seeking understanding: An introduction to Christian theology. Grand Rapids, Mi: Eerdmans.

Moreau, A.S., Corwin,G.R. \& McGee, G.B. 2004. Introducing world missions: a Biblical, historical and Practical survey. Grand Rapids Mi: Baker Academic.

O'Brien, P.T. 1995. Gospel and mission in the writings of Paul: an exegetical and theological analysis. Grand Rapids: Baker books.

O’Brien, P.T. 2002. Vol. 44: Word Biblical Commentary : Colossians-Philemon. Word Biblical Commentary (31-63). Dallas: Word, Incorporated.

Okure, T. 2002. "In him all things hold together: A missiological reading of Colossians 1:15-20. International Review of Mission 91(360): 62-72.

Peterson, R.A. 2010. "To reconcile to himself all things". Presbyterion 36 (1):37-46.

Pokorný, P. 1987. Der Brief des Paulus an die Kolosser. Theologischer Handkommentar zum Neuen Testament 10/1. Berlin: Evanglische Verlagsanstalt.

Roberts, J.H. 1984. Die Gevangeskapsbriewe. In Du Toit, A.B. (Red). Die Pauliniese briewe: Inleiding en teologie. Handleiding by die Nuwe Testament Band V. Pretoria: NG Kerkboekhandel, 114-157.

Schnelle, U. 2005. Apostle Paul: his life and theology (Translated by M.E. Boring). Grand Rapids: Baker Academic.

Shultz, G. 2010. The reconciliation of all things in Christ. Bibliotheca Sacra 167(668):442-459.

Schweizer, E. 1982. The letter to the Colossians: A commentary. (Translated by A Chester). Minneapolis: Augsburg.

Smit, D.1986. Christus is die Heer! Oordenkings en Bybelstudie uit die Kolossensebrief. Kaapstad: Lux Verbi.

Standhartinger, A. 1999. Studien zur Entstehungschichte \& Intention des Kolosserbriefs. Leiden: Brill.

Thompson, M.M. 2005. Colossians and Philemon. Grand Rapids Mi: Eerdmans. [The two horizons New Testament commentary].

Thurston, B. 1995. Reading Colossians, Ephesians \& 2 Thessalonians: A Literary and theological commentary. New York: Crossroad.

Trevethan, T.L. 1981. Our joyful confidence: The Lordship of Jesus in Colossians. An exposition. Downers Grove: InterVarsity.

Tripp, D. 2004. katoikēsai, katoikei (Colossians 1:19, 2:9): Christology, or soteriology also?: Expository Times 116(3):78-79.

Uitman, J.E. 1978. De brief van Paulus aan de Colossenzen. Nijkerk: Callenbach. [De Prediking van het Nieuwe Testament].

Van der Walt, B.J. 2003. Understanding en rebuilding Africa: From desperation today to expectation for tomorrow. Potchefstroom: ICCA.

Wall, R.W. 1993. Colossians and Philemon. Downers Grove: InterVarsity. [The IVP New Testament Commentary Series]

Walsh, B.J. \& Keesmaat, S.C. 2004. Colossians remixed: Subverting the Empire. Downers Grove: IVP Academic.

Webster, W. 1982. The messenger and mission societies. In Winter, R.D. and Hawthorne, S.C. Perspectives on the world Christian movement: A Reader. Pasadena: William Carey Library: 763-769.

Wilson, W.T. 1997. The hope of glory: Education \& exhortation in the epistle to the Colossians. Leiden: Brill.

Witherington III, B. 2007. The letters to Philemon, the Colossians and the Ephesians: A socio-rethorical commentary on the captivity epistles. Grand Rapids: Eerdmans. 


\section{TREFWOORDE}

Kolossense 1

Christus, Hoof van kerk en kosmos

Volledige versoening

Sendingimplikasies

\section{KEY WORDS}

\section{Colossians 1}

Christ, Head of church and cosmos

Encompassing salvation

Mission implications

Prof Pieter Verster

Hoof, Departement Sendingwetenskap, Fakulteit Teologie, Universiteit van die Vrystaat, Bloemfontein, 9300. Suid-Afrika.

E-pos: versterp@ufs.ac.za

Tel +27(0)514364466

Sel $+27(0) 823756793$

Faks $+27(0) 514013508$ 